WARSZTATY Z GEOGRAFII TURYZMU

ISBN 978-83-7969-262-0 $\quad$ s. 39-49

http://dx.doi.org/10.18778/7969-262-0.03

Włodzimierz KUREK

Uniwersytet Jagielloński w Krakowie

\title{
KARPATY W OPRACOWANIACH NAUKOWYCH GEOGRAFÓW Z ZAKŁADU GOSPODARKI TURYSTYCZNEJ I UZDROWISKOWEJ UNIWERSYTETU JAGIELLOŃSKIEGO
}

Rozwój badań nad turystyką postępuje w tak dużym tempie, że obecnie trudno jest zgłębić całą literaturę dotyczącą tego tematu i, co za tym idzie, precyzyjnie określić pola badawcze oraz wkład geografii turyzmu do dorobku omawianej dyscypliny naukowej. Jest oczywiste, że w wypadku krakowskiego ośrodka geografii turyzmu na wybór problematyki badawczej decydujący wpływ mają: dziedzictwo kulturowe Krakowa i położenie w pobliżu Karpat. W związku z tym nie dziwi fakt, iż najważniejszym obszarem badań pracowników Zakładu Gospodarki Turystycznej i Uzdrowiskowej Instytutu Geografii i Gospodarki Przestrzennej UJ są polskie Karpaty. W niniejszym opracowaniu, którego celem jest pokazanie wkładu geografów z Zakładu Gospodarki Turystycznej i Uzdrowiskowej UJ w rozwój badań nad turystyką, skupiono się więc na tym jednym regionie.

Przegląd i ocenę dorobku naukowego z zakresu badań nad turystyką w polskich Karpatach znaleźć można m.in. w opracowaniach J. WARSZYŃSKIEJ (1992) oraz W. KURKA i R. PAWLUSIŃSKIEGO (2008). Od tego czasu napisano jednak wiele nowych prac (a tylko niektóre $\mathrm{z}$ nich opublikowano) wpisujących się $\mathrm{w}$ nurt kierunków badawczych pracowników i doktorantów Zakładu i odzwierciedlających ich zainteresowania naukowe.

Przedstawiając problematykę współczesnych badań z zakresu geografii turyzmu prowadzonych w Karpatach nie można nie wspomnieć o doko- 
naniach tych uczonych, którzy wnieśli do nich największy wkład, bowiem stworzyli podstawy do ich dalszego rozwoju. Byli nimi niewątpliwie Stanisław Leszczycki i Jadwiga Warszyńska.

S. Leszczycki, założyciel Studium Turyzmu UJ, które działało w latach 1936-1939, zajmował się m.in. problemami rozwoju wsi letniskowych i uzdrowisk w Karpatach oraz zagadnieniami ruchu turystycznego (LESZCZYCKI 1939).

Przedmiotem zainteresowań naukowych J. WARSZYŃSKIEJ (1974, 1985) były natomiast metody oceny środowiska przyrodniczego dla potrzeb turystyki (1974) oraz zagadnienie rozwoju funkcji turystycznej Karpat Polskich (1985).

Główne kierunki badań prowadzonych obecnie przez pracowników i doktorantów Zakładu Gospodarki Turystycznej i Uzdrowiskowej UJ dotyczą przede wszystkim: przestrzennego zróżnicowania stanu rozwoju turystyki, przemian $\mathrm{w}$ zagospodarowaniu turystycznym wynikających $\mathrm{z}$ transformacji społeczno-ekonomicznej kraju, społecznych, ekonomicznych i przyrodniczych skutków rozwoju turystyki, funkcji turystycznych na obszarach chronionych, przemian leczniczej i wypoczynkowej funkcji uzdrowisk oraz ważniejszych form turystyki, a w tym: turystyki pieszej, narciarskiej, wiejskiej, zdrowotnej, kulturowej oraz wypoczynku weekendowego.

I tak, badania W. KURKA (2003, 2005a, b, 2008, 2011) skupiają się na zagadnieniach dotyczących współpracy transgranicznej $\mathrm{w}$ ramach euroregionów (KUREK 2003, 2005a), na określeniu stanu rozwoju funkcji turystycznej obszarów górskich (KUREK 2005b, c), na analizie przemian w organizacji, zagospodarowaniu i ruchu turystycznym w czasie transformacji ustrojowej (KUREK 2008a), na określeniu sytuacji miejscowości turystycznych w dobie konkurencji (KUREK, MIKA 2008), na możliwościach rozwoju turystyki międzynarodowej (KUREK, PAWLUSIŃSKI 2009) oraz na ustaleniu roli kultury ludowej w rozwoju turystyki na obszarze Karpat (KUREK 2011).

D. Ptaszycka-Jackowska zajmuje się problematyką gospodarki przestrzennej, zagadnieniami przyrodniczych obszarów chronionych oraz turystyką. Swoimi badaniami obejmuje szczególnie Babią Górę i jej otoczenie. Gospodarce przestrzennej badaczka poświęciła publikację zatytułowaną Gospodarowanie przestrzenią (PTASZYCKA-JACKOWSKA 2006), w której zwraca uwagę na problemy ładu przestrzennego, na różne wartości przestrzeni, na skalę gospodarowania oraz na gospodarowanie przestrzenią w czasie, przytaczając różnorodne przykłady z obszaru polskich Karpat. We wcześniejszej pracy na temat zagospodarowania przestrzennego Karpat Polskich D. PTASZYCKA- 
-JACKOWSKA (2002a) przedstawiła różnorodne typy opracowań planistycznych, w tym - o charakterze ogólnopolskim, makroregionalnym oraz strategie wojewódzkie. Zwróciła też uwagę na szczególne uwarunkowania zagospodarowania przestrzennego Karpat i zaproponowała pożądaną hierarchię funkcji występujących na badanym obszarze. W kolejnej pracy dotyczącej gospodarowania przestrzenią turystyczną (PTASZYCKA-JACKOWSKA 2007) autorka określiła rzeczywistą i potencjalną przestrzeń turystyczną w Karpatach Polskich, zwracając uwagę na jej poszerzenia w postaci rezerwatów biosfery i euroregionów sięgających aż poza granice kraju. Również w tym wypadku autorka wskazała główne problemy gospodarowania oraz miejsce turystyki w hierarchii funkcji polskich Karpat. Z kolei w opracowaniu zatytułowanym Zmiany w strukturach przestrzennych przyrodniczych obszarózv chronionych w Polsce (PTASZYCKA-JACKOWSKA 2009), dotyczącym rejonu Babiej Góry, D. Ptaszycka-Jackowska zajęła się problematyką relacji przestrzeń a ochrona przyrody. Podjęła w nim problematykę rezerwatów biosfery i obszarów Natura 2000 w planowaniu przestrzennym (PTASZYCKA-JACKOWSKA 2011). W innym artykule zatytułowanym Sacrum w parkach narodowych w polskich Karpatach (PTASZYCKA-JACKOWSKA 2005a) przedmiotem zainteresowań badaczki stały się obiekty sakralne znajdujące się w karpackich parkach narodowych w Polsce. Powstały one zarówno przed utworzeniem danych parków, jak i w trakcie ich funkcjonowania i do tej pory odgrywają tam ważną rolę kulturową i turystyczną. Z kolei rezultatem wieloletnich badań zjawisk turystycznych i ochrony przyrody we Francji jest opracowanie pt. Francuskie parki regionalne jako punkt odniesienia dla polskich parkówo krajobrazowoych (PTASZYCKA-JACKOWSKA 2008) (w tym również karpackich), w którym autorka skupia swą uwage głównie na organizacyjnych, finansowych oraz społecznych problemach parków krajobrazowych.

Problematykę rozwoju turystyki na obszarze polskich Karpat w warunkach przemian społeczno-gospodarczych podejmował także M. Mika. Autor szczególnie wiele uwagi poświęcił zmianom w sektorze turystyki narciarskiej, w tym zagadnieniom ograniczeń jej rozwoju oraz sytuacjom konfliktowym (MIKA, KRZESIWO, KRZESIWO 2007, 2009), a także atrakcyjności stacji narciarskich w świetle ich konkurencyjności (KRZESIWO, MIKA 2011). W jego dorobku sporo miejsca zajmują też opracowania dotyczące przekształceń strukturalno-funkcjonalnych miejscowości uzdrowiskowych (MIKA 2005) oraz rozwoju nowych form turystyki zdrowotnej (MIKA, PAWLUSIŃSKI 2006). Ważnym polem badawczym M. Miki była też problematyka „drugich domów" na obszarze polskich Karpat, w tym ich przestrzenny rozwój oraz 
wpływ na przemiany obszarów wiejskich (MIKA, FARACIK 2008, MIKA 2012, 2013). Istotne novum w badaniach $\mathrm{z}$ zakresu geografii turyzmu stanowi obecnie zagadnienie konkurencyjności obszarów recepcji turystycznej. Również tym tematem, w odniesieniu do polskich Karpat, zajmował się M. MIKA (2010, KUREK, MIKA 2008). W pracy pt. Założenia i determinanty podtrzymywoalności lokalnego rozwoju turystyki (MIKA 2014) autor podjął próbę określenia czynników oraz mechanizmów warunkujących utrzymanie ciągłości rozwojowej miejscowości turystycznych cechujących się wysoką złożonością i nasileniem zjawisk turystycznych.

Znaczna część Karpat spełnia funkcję terenów przeznaczonych do wypoczynku krótkookresowego mieszkańców miast leżących wzdłuż północnej granicy omawianego obszaru, zwłaszcza Krakowa i miast GOP. Tym zagadnieniem zajął się z kolei R. FARACIK (2006) w badaniach strefy podmiejskiej Krakowa, obejmującej dużą część Karpat. Ich celem było określenie stopnia rozwoju i charakteru funkcji turystycznej na obszarze gmin znajdujących się w omawianej strefie oraz wskazanie możliwych kierunków jej dalszego rozwoju. Południowa część podmiejskiej strefy Krakowa obejmuje obszar dysponujący wysokimi walorami krajobrazowymi i kulturowymi. Układ przestrzenny zagospodarowania turystycznego (baza noclegowa, drugie domy, kąpieliska) nawiązuje tu w głównej mierze do przebiegu doliny rzeki Raby, gdzie koncentruje się znaczna część jednodniowego ruchu turystycznego o charakterze wypoczynkowym. Rozwój bazy noclegowej związany jest tu także z głównymi szlakami komunikacyjnymi. Model turystyki w tej części podmiejskiej strefy Krakowa rozwija się przede wszystkim $\mathrm{w}$ oparciu o atrakcyjność środowiska przyrodniczego dla form turystyki rekreacyjnej. $\mathrm{Na}$ południowych obrzeżach omawianej strefy celom wypoczynkowym służą też liczne drugie domy. Wyróżniającymi się ośrodkami turystycznymi strefy podmiejskiej Krakowa, o znaczeniu międzynarodowym, są Wieliczka i Kalwaria Zebrzydowska. W omawianej pracy autor podjął też próbę typologii gmin strefy podmiejskiej Krakowa ze względu na stopień rozwoju funkcji turystycznej oraz jej strukturę.

Badania R. Pawlusińskiego w Karpatach Polskich dotyczyły głównie uwarunkowań i stanu rozwoju turystyki oraz jej wybranych form. W swoich pracach autor przedstawił, z punktu widzenia głównych form ruchu turystycznego, potencjał turystyczny w Karpatach, a także: wielkość i strukturę ruchu turystycznego oraz bazy turystycznej, a także możliwe kierunki rozwoju turystycznego. Przedmiotem badań były województwa: podkarpackie 
i małopolskie oraz miasta karpackie i uzdrowiska (PAWLUSIŃSKI, MIKA 2006, PAWLUSIŃSKI 2009, 2012).

Obszerne badania prowadzono także w karpackich parkach krajobrazowych. I tak w pracy pt. Możliwości rozwoju turystyki w parkach krajobrazowych Karpat Polskich w śivietle idei zrówonoważonego rozwoju B. ZAWILIŃSKA (2010) dokonała szczegółowej analizy uwarunkowań rozwoju turystyki w 13 parkach karpackich. Autorka przedstawiła w niej stan zagospodarowania turystycznego $\mathrm{w}$ badanych parkach oraz formy i rozmieszczenie ruchu turystycznego. Podjęła też próbę oceny wprowadzenia na badanym obszarze zrównoważonego rozwoju turystyki. Analiza uwarunkowań rozwoju turystyki dotyczyła m.in. położenia parków, ich walorów przyrodniczych i kulturowych oraz społeczno-ekonomicznej sytuacji parków. Stan zagospodarowania turystycznego parków karpackich autorka ustaliła na podstawie inwentaryzacji wszystkich obiektów infrastruktury turystycznej. Z jej badań wynika, że wszystkie parki krajobrazowe mają sprzyjające warunki do rozwoju funkcji turystycznej, a ich atrakcyjność związana jest głównie z walorami przyrodniczymi i kulturowymi. Najlepsze walory mają parki Beskidu Śląskiego, Żywiecki, Beskidu Małego, Popradzki oraz Ciśniańsko-Wetliński i Doliny Sanu. Wielkość ruchu turystycznego najbardziej zależy tu jednak od położenia względem dużych ośrodków miejskich i od dostępności komunikacyjnej. W związku z tym największe natężenie ruchu turystycznego notuje się w parkach Beskidu Śląskiego, Żywieckim, Beskidu Małego, Wiśnicko-Lipnickim oraz Ciężkowicko-Rożnowskim, które położone są w strefie wyjazdów weekendowych oraz jednodniowych. Możliwe kierunki rozwoju turystyki w parkach karpackich uzależnione są przede wszystkim od stopnia rozwoju funkcji turystycznej, jej znaczenia w strukturze gospodarczej miejscowości i gmin oraz od walorów turystycznych i położenia względem głównych obszarów emisji ruchu turystycznego.

W ramach badań nad uzdrowiskami karpackimi powstało też obszerne, nieopublikowane studium E. ROGERS (2010) pt. Kierunki przekształceń karpackich uzdrowisk Polski i Słowacji wo warunkach gospodarki wolnorynkowej. Przedmiotem analizy były w nim 24 uzdrowiska położone w obrębie polskiej i słowackiej części Karpat, a zakres czasowy badań obejmował lata 19892008. Praca zawiera analizę uwarunkowań i wyniki badań nad stanem rozwoju polskich i słowackich uzdrowisk karpackich oraz ocenę przemian przestrzennych, społeczno-gospodarczych i funkcjonalnych miejscowości uzdrowiskowych. Efektem badań było też wskazanie kierunków dalszego kształtowania funkcji uzdrowiskowej i turystycznej omawianych miejscowości. 
Praca zajmuje się również zagadnieniem konkurencyjności uzdrowisk (konkurencyjność produktowa, jakościowa, cenowa i inwestycyjna).

Przedmiotem (również nieopublikowanych) badań B. BIELAK (2009) były z kolei zbiorniki zaporowe znajdujące się w obrębie polskich Karpat. Zbiorniki należą do miejsc o największej koncentracji ruchu turystycznego. Mają duże znaczenie dla wypoczynku mieszkańców miast, leżących zwłaszcza w obrębie samych Karpat i na terenach położonych w strefie na północ od nich. Badania B. Bielak polegały na inwentaryzacji wszystkich obiektów bazy noclegowej, gastronomicznej oraz komunikacyjnej, a także na określeniu, na podstawie ankiet (700), wielkości i charakteru ruchu turystycznego. Pozwoliło to ukazać zróżnicowanie zbiorników pod względem ich specyfiki, stopnia zagospodarowania oraz wielkości i struktury ruchu turystycznego. Badania umożliwiły ponadto zapoznanie się $\mathrm{z}$ opiniami turystów na temat walorów przyrodniczych i kulturowych badanych obszarów, zagospodarowania turystycznego oraz potrzeb w zakresie infrastruktury turystycznej.

Jak wiadomo, Karpaty są w Polsce najważniejszym i najintensywniej zagospodarowanym regionem narciarskim. W wielu miejscowościach turystyka narciarska jest głównym czynnikiem wpływającym na ich rozwój - społeczny i gospodarczy. Ze względu na masowy charakter i wielkość obrotów finansowych stanowi ona również dla wielu regionów górskich ważny sektor zatrudnienia i źródło dochodów. Rozwój i funkcjonowanie stacji narciarskich w Karpatach Polskich były przedmiotem badań K. KRZESIWO (2014). Ich celem było przedstawienie procesu rozwoju zagospodarowania badanych terenów dla narciarstwa, ukazanie jego obecnego stanu, a także określenie uwarunkowań, kierunków oraz barier rozwoju ośrodków i stacji narciarskich. Badania (prowadzone w roku 2012) objęły 118 miejscowości wyposażonych w infrastrukturę dla narciarstwa zjazdowego. Szczegółowo natomiast zbadano 16 miejscowości o najlepiej rozwiniętej infrastrukturze narciarskiej oraz o zdolności przewozowej urządzeń wyciągowych powyżej 5000 osób/godz. Były to: Białka Tatrzańska, Brenna, Bukowina Tatrzańska, Czarna Góra, Korbielów, Krynica, Małe Ciche, Szczyrk, Ustroń, Ustrzyki Dolne, Wierchomla, Wisła, Witów, Zakopane, Zawoja oraz Zwardon. Pracę oparto głównie na materiałach uzyskanych w trakcie badań terenowych, polegających na inwentaryzacji i kartowaniu infrastruktury narciarskiej oraz na przeprowadzaniu wywiadów z narciarzami (1978 osób) w 16 stacjach narciarskich i z gestorami ośrodków narciarskich (35 osób). Badania te umożliwiły przedstawienie stanu infrastruktury narciarskiej w badanych stacjach, 
ocenę atrakcyjności stacji w opinii turystów oraz ukazanie barier w rozwoju ośrodków narciarskich.

Jedną z najważniejszych konsekwencji przemian ustrojowych w ostatnich dwóch dekadach było ożywienie wymiany gospodarczej, kulturalnej, a także turystycznej na pograniczu polsko-słowackim. Zagadnienie to stało się przedmiotem nieopublikowanego opracowania B. PIZIAKA (2013) pt. Turystyka na pograniczu polsko-stowackim - stan i perspektywy rozwoju (2013). Efektem badań autora było ustalenie stanu, kierunków rozwoju oraz roli turystyki w rozwoju społeczno-gospodarczym omawianego obszaru. Autor podjął też próbę nakreślenia przyszłych kierunków rozwoju turystyki na terenach pogranicza polsko-słowackiego.

M. Kubal jest natomiast w trakcie opracowywania tematu pt. Agroturystyka jako czynnik aktywizacji zawoodowej kobiet na obszarach górskich województwa małopolskiego. Jej badania dotyczą motywów podjęcia działalności agroturystycznej, określenia czynników aktywizacji zawodowej kobiet w działalności agroturystycznej, określenia form aktywizacji zawodowej kobiet pracujących w gospodarstwach agroturystycznych, a także ustalenia wpływu wzrostu aktywności zawodowej kobiet pracujących w agroturystyce na zmiany w relacjach $\mathrm{w}$ rodzinie oraz stopnia zaangażowania kobiet prowadzących działalność agroturystyczną w działalność na rzecz społeczności lokalnej.

Częściowym podsumowaniem badań nad kierunkami i skutkami transformacji turystyki na obszarze polskich Karpat jest zbiorowa publikacja pt. Turystyka w Karpatach Polskich w świetle wspótczesnych kierunków rozwoju (FARACIK, KUREK, MIKA, PAWLUSIŃSKI 2009).

Z ważniejszych projektów badawczych zrealizowanych w Zakładzie Gospodarki Turystycznej i Uzdrowiskowej UJ wymienić trzeba projekt wykonany w latach 2005-2008 w ramach Programu Środowiskowego ONZ pt. Conservation and sustainable use of biodiversity through sound tourism development in Biosphere Reserves in Central and Eastern Europe (GFL/238-2714-4829). Dotyczył on kwestii rozpoznania i wskazania możliwości wdrażania zasad harmonijnego rozwoju turystyki na obszarze i w otoczeniu Rezerwatu Biosfery Babia Góra. Naukowe efekty wykonanych prac zawarto w raporcie końcowym pt. Plan rozwoju $i$ zarządzania turystyka w regionie Babiej Góry (PAWLUSIŃSKI, MIKA, FARACIK 2008).

W najbliższej przyszłości w badaniach pracowników i doktorantów Zakładu Gospodarki Turystycznej i Uzdrowiskowej Instytutu Geografii i Gospodarki Przestrzennej UJ należałoby się skupić zwłaszcza na zagadnieniach dotyczących: 
1) skutków rozwoju niektórych form turystyki (a przede wszystkim szybko rozwijającego się narciarstwa) w odniesieniu do środowiska przyrodniczego;

2) ochrony środowiska przyrodniczego $w$ parkach narodowych ze wzmożonym ruchem turystycznym (zwłaszcza TPN i PPN);

3) przemian kulturowych dokonujących się pod wpływem turystyki (zwłaszcza przemian kultury ludowej w kontekście zachowania jej autentyczności);

4) większego wykorzystania Karpat jako obszaru wypoczynku weekendowego;

5) możliwości rozwoju uzdrowisk karpackich;

6) nowych form turystyki i rekreacji.

Pewne kroki w tej mierze już poczyniono.

\section{LITERATURA}

BIELAK B., 2009, Funkcja turystyczna zbiorników zaporowych i ich otoczenia w Karpatach Polskich, Uniwersytet Jagielloński, Instytut Geografii i Gospodarki Przestrzennej, mpis pracy doktorskiej.

FARACIK R., 2006, Turystyka w strefie podmiejskiej Krakowa, Instytut Geografii i Gospodarki Przestrzennej, Uniwersytet Jagielloński, Kraków.

FARACIK R., KUREK W., MIKA M., PAWLUSIŃSKI R., 2009, Turystyka w Karpatach polskich w świetle wspótczesnych kierunków rozwoju, [w:] B. Domański, W. Kurek (red.), Gospodarka i przestrzeń, Instytut Geografii i Gospodarki Przestrzennej, Uniwersytet Jagielloński, Kraków, s. 77-98.

KRZESIWO K., 2014, Rozwój i funkcjonowanie stacji narciarskich w Karpatach Polskich, Kraków.

KUREK W., 2003, Development conditions of Polish sector of the Carpathian Euroregion, [w:] Z. Gorka (red.), Changes of geographical environment and those of the socio-economic phenomena, Prace Geograficzne IGiGP UJ, 112, s. 149-159.

KUREK W., 2005a, Developing the Euroregions along the Polish-Slovak Border, [w:] Foreign Direct Investment and Regional Development in East Central Europe and the Former Soviet Union. A Colletion of Essays in Memory of Professor Francis Frank Carter, ed. D. Turnock, Ashgate, s. 291-304.

KUREK W., 2005b, Turystyczna funkcja obszarów górskich, „Turyzm”, 15, 1-2, s. 151-162.

KUREK W., 2005c, Wptyw turystyki na środowisko przyrodnicze obszarów górskich, [w:] B. Domański, S. Skiba (red.), Geografia i sacrum, t. 2, IGiGP UJ, Kraków, s. 95-104.

KUREK W., 2008, Tourism on the Polish Carpathians in the political transition time, [w:] J. Wyrzykowski (red.), Conditions of the foreign tourist development in Central and Eastern Europe, 10, Uniwersytet Wrocławski, Wrocław, s. 295-302.

KUREK W., 2011, Kultura ludowa jako element atrakcyjności obszarów wiejskich, [w:] B. Włodarczyk (red.) Turystyka, Ksiega jubileuszowa w 70. rocznice urodzin Profesora Stanisława Liszewskiego, Wyd. Uniwersytetu Łódzkiego, s. 365-374.

KUREK W., MIKA M., 2008, Miejscowości turystyczne w dobie konkurencji (na przykładzie Karpat Polskich), [w:] G. Gołembski (red.), Turystyka jako czynnik wzrostu konkurencyjności regionów w dobie globalizacji, Wyd. AK w Poznaniu, Poznań, s. 219-228. 
KUREK W., PAWLUSIŃSKI R., 2008, Dziatalność naukowo-badawcza i dydaktyczna w zakresie turystyki w Zakładzie Gospodarki Turystycznej i Uzdrowiskowej Instytutu Geografii i Gospodarki Przestrzennej Uniwersytetu Jagiellońskiego, [w:] G. Gołembski (red.), Nowe trendy rozwoju turystyki, Wyd. PWSZ, Sulechów, s. 25-38.

KUREK W., PAWLUSIŃSKI R., 2009, Stan i perspektywy rozwoju turystyki międzynarodowej w województwie matopolskim (International tourism in matopolskie województwo. The present situation and prospects for development, p. 53-58), ,Turyzm”, 19, 1-2, s. 53-59.

LESZCZYCKI S., 1939, Podstawy gospodarki uzdrowiskowo-letniskowej w Karpatach, Prace Studium Turyzmu Uniwersytetu Jagiellońskiego, 5.

MiKA M., 2005, Możliwości rozwoju uzdrowisk Beskidu Niskiego i Bieszczad w świetle obecnych uwarunkowań, [w:] E. Rydz (red.), Kształtowanie funkcji turystycznych w miejscowościach uzdrowiskowych, Pomorska Akademia Pedagogiczna w Słupsku, Słupsk, s. 308-318.

MIKA M., 2009, Ski tourism in the Polish Carpathians - present state and issues of development, „Folia Geographica. Acta Facultatis Studiorum Humanitatis et Naturae Universitatis Presoviensis", 14, s. $198-208$.

MIKA M., 2010, Regional and cross-border competition as a development factor in tourist reception areas in the Western Carpathians, [w:] D. Richard (red.), Development durable des territories: de la mobilisation des acteurs aux demarches pearticipatives, Wyd. Universitarires Blaise Pascal, Clermont-Ferrand, s. 317-330.

MIKA M., 2012, Kierunki i cechy rozwoju drugich domów w polskich Karpatach w świetle stanu badań, „Czasopismo Geograficzne" 83(1-2), s. 63-79.

MIKA M., 2013, Spatial patterns of second homes development in the Polish Carpathians, [w:] J. Kozak, K. Ostapowicz, A. Bytnerowicz, B. Wyżga (red.), Integrating nature and society towards sustainability, Environmental Science and Engineering, Springer-Verlag, Berlin Heidelberg, s. 479-512.

MIKA M., 2014, Zatożenia i determinanty podtrzymywalności lokalnego rozwoju turystyki, Instytut Geografii i Gospodarki Przestrzennej, Uniwersytet Jagielloński, Kraków.

MIKA M., FARACIK R., 2008, Second homes as a factor of the transformation of rural areas in the Polish Carpathians, „Folia Geographica. Acta Facultatis Studiorum Humanitatis et Naturae Universitatis Presoviensis" 12, s. 245-255.

MIKA M., KRZESIWO K., 2011, Ocena atrakcyjności turystycznej stacji narciarskich w świetle zagadnienia ich konkurencyjności - studium porównawcze Szczyrku i Białki Tatrzańskiej, „Prace Geograficzne” 125, s. 95-110.

MIKA M., KRZESIWO K., KRZESIWO P., 2007, Wspótczesne problemy rozwoju ośrodków narciarskich w Polsce - przykład Szczyrku, „Prace Geograficzne” 117, s. 63-78.

MIKA M., KUREK W., 2008, Miejscowości turystyczne w dobie konkurencji (na przykładzie polskich Karpat), [w:] G. Gołembski (red.), Turystyka jako czynnik wzrostu konkurencyjności regionów w dobie globalizacji, Wyd. Akademii Ekonomicznej w Poznaniu, Poznań, s. 219-228.

MIKA M., PAWLUSIŃSKI R., 2006, Some problems of the development of spa \& wellness services in the Polish Carpathian Mountains, [w:] J. Wyrzykowski (red.), Conditions of the foreign tourist development in Central and Eastern Europe, Contemporary Models of Spa Tourism, 9, Uniwersytet Wrocławski, Wrocław, s. 61-73.

PAWLUSIŃSKI R., 2009, Turystyka w województwie podkarpackim, „Folia Geographica, Series Geographica-Oeconomica", PAN, Kraków, vol. XXXIII, s. 119-136.

PAWLUSIŃSKI R., 2012, Turystyka w miastach przygranicznych Karpat Polskich w świetle wspótczesnych kierunków rozwoju, [w:] P. Sadowski (red.), Rozwój turystyki kulturowej i przyrodniczej na pograniczu polsko-stowackim, PPWSZ, Nowy Targ, s. 31-38.

PAWLUSIŃSKI R., MIKA M., FARACIK R. 2008, Plan rozwoju i zarzqdzania turystyka w regionie Babiej Góry, Kraków, s. 122. 
PIZIAK B., 2013, Turystyka na pograniczu polsko-stowackim - stan i perspektywy rozwoju, Uniwersytet Jagielloński, Instytut Geografii i Gospodarki Przestrzennej (praca doktorska).

PTASZYCKA-JACKOWSKA D., (red.), 2005b, Światy Babiej Góry, wyd. 2. Babiogórski Park Narodowy, Zawoja.

PTASZYCKA-JACKOWSKA D., 2002, Zagospodarowanie przestrzenne Karpat Polskich w opracowaniach planistycznych, „Problemy Zagospodarowania Ziem Górskich” 48, s. 43-57.

PTASZYCKA-JACKOWSKA D., 2005a, Sacrum w parkach narodowych w polskich Karpatach, [w:] B. Domański, S. Skiba (red.), Geografia i sacrum, t. 2, Instytut Geografii i Gospodarki Przestrzennej UJ, Kraków, s. 389-402.

PTASZYCKA-JACKOWSKA D., 2006, Gospodarowanie przestrzeniq, „Alma Mater” 85, Uniwersytet Jagielloński, Kraków, 85, s. 12-14.

PTASZYCKA-JACKOWSKA D., 2007, Gospodarowanie przestrzeniq turystycznq w Polskich Karpatach, [w:] D. Ptaszycka-Jackowska (red.), Polska przestrzeń turystyczna, Prace Geograficzne IGiGP UJ 117, s. 99-112.

PTASZYCKA-JACKOWSKA D., 2008, Francuskie parki regionalne jako punkt odniesienia dla polskich parków krajobrazowych, [w:] K. Zieniewicz (red.), Bariery w zarzadzaniu parkami krajobrazowymi w Polsce, PWE, Warszawa, s. 142-150.

PTASZYCKA-JACKOWSKA D., 2009, Zmiany $w$ strukturach przestrzennych przyrodniczych obszarów chronionych $w$ Polsce, [w:] I. Jażewicz (red.), Wspótczesne problemy przemian strukturalnych przestrzeni geograficznej, Akademia Pomorska w Słupsku, s. 169-180.

PTASZYCKA-JACKOWSKA D., 2011, Rezerwaty Biosfery i Obszary Natura 2000 w planowaniu przestrzennym, [w:] A. Breymeyer (red.), Międzynarodowa Sieć Obszarów Chronionych w Polsce: Światowa Sieć Rezerwatów Biosfery, UNESCO-MAB i Europejska Sieć Natura 2000, Warszawa, s. 13-23.

ROGERS E., 2010, Kierunki przekształceń karpackich uzdrowisk Polski i Stowacji w warunkach gospodarki wolnorynkowej, Uniwersytet Jagielloński, Instytut Geografii i Gospodarki Przestrzennej (praca doktorska).

WARSZYŃSKA J., 1974, Ocena zasobów środowiska naturalnego dla potrzeb turystyki (na przykładzie woj. krakowskiego), Zeszyty Naukowe UJ. Prace Geograficzne IGiGP UJ 36.

WARSZYŃSKA J., 1985, Funkcja turystyczna Karpat Polskich, Folia Geographica, ser. Geographica Oeconomica, 18, s. 79-104.

WARSZYŃSKA J., 1992, Geografia turyzmu w Instytucie Geografii Uniwersytetu Jagiellońskiego po drugiej wojnie światowej, Prace Geograficzne IGiGP UJ, 89.

ZAWILIŃSKA B., 2010, Możliwości rozwoju turystyki w parkach krajobrazowych Karpat Polskich w świetle idei zrównoważonego rozwoju, Monografie: Prace Doktorskie, 8, Uniwersytet Ekonomiczny w Krakowie, Kraków.

\section{THE CARPATHIANS IN SCIENTIFIC PAPERS OF GEOGRAPHERS FROM THE DEPARTMENT OF TOURISM AND HEALTH RESORT MANAGEMENT AT JAGIELLONIAN UNIVERSITY}

Key words: Polish Carpathians, tourism, science publications

\section{Summary}

The main directions of research carried out by staff and graduate students of the Department of Tourism and Health Resort Management at Jagiellonian University relate primarily to: spatial differentiation of tourism development, changes in the management of tourism resulting from socioeconomic transformation of the country, social, economic and natural effects of tourism, tourism in 
protected areas, changes of medical and leisure functions of spa resorts and important forms of tourism, including: hiking, ski tourism, rural tourism, health tourism, cultural tourism and weekend stays.

In the near future research should primarily focus on issues relating to: the effects of the development of certain forms of tourism for the environment (especially the rapidly developing ski tourism), environmental protection in national parks with increased tourist traffic (especially Tatrzański National Park and Pieniński National Park), the cultural changes under the influence of tourism (especially transformations of the folk culture in the context of the preservation of its authenticity), greater use of the Carpathians as a weekend stays and leisure area, the opportunities of development of the Carpathian spas and new forms of tourism and recreation. 